\title{
The information needs of United Kingdom Members of the European Parliament (MEPs)
}

\section{Rita Marcella, Iona Carcary and Graeme Baxter}

\begin{abstract}
:
This paper details the results of a Masters project investigating attitudes amongst decision-makers in the European Parliament to the role of information in their work, and their ability to identify, access and evaluate that information most relevant to their needs. The main aims of the research were to elicit data regarding levels of satisfaction amongst MEPs in relation to information retrieval, and to identify areas of information need which were not being addressed. The research methodology consisted of a postal survey of United Kingdom MEPs, achieving a 34\% response rate. The results included: the wide range of subjects that are of interest to MEPs; that all MEPs have research assistants to help in their work, with an average of 3.5 assistants per MEP; the majority of these assistants are based in the UK and are employed full-time; and that the most popular sources were unofficial, informal contacts and MEPs own files, as opposed to the official European Union databases and services. The main problems faced by MEPs in information retrieval are pressure of time and the overwhelming number and variety of information sources available. Recommendations are made for further research into the information needs of MEPs and information management practices within the European Union.
\end{abstract}

\section{Introduction and background}

The role of information in the decision-making process has been investigated in a number of subject areas, most notably in relation to business and medicine: however, there has been relatively little investigation of information use as part of the political decision-making process, in particular in the European context. This project investigates attitudes amongst decision-makers in the European Parliament to the role of information in their work, and assesses their ability to identify, access and evaluate that information most relevant to their needs.

The main aims of the research were as follows:

- $\quad$ to gather data on areas of information need and information seeking preferences amongst UK Members of the European Parliament and their researchers;

- to identify levels of satisfaction amongst MEPs regarding present information retrieval methods, speed of access and relevance;

- $\quad$ to identify problems encountered presently by MEPs in retrieving information. 


\section{Project Methodology}

The research project methodology consisted of two elements: an initial postal questionnaire to the 8 MEPs for Scottish constituencies; and a postal questionnaire to the 79 MEPs representing the rest of the UK constituencies. Despite the fact that no piloting of the questionnaire was carried out respondents answered most questions clearly. The questionnaire used in stage one (Scottish MEPs) underwent a minor modification and was distributed to the remaining UK MEPs. Four apologies were received, in lieu of completed questionnaires, from MEPs unable to assist in the research project due to constraints on their time. The overall survey response rate was $34 \%$ (30 responses). This response rate is acceptable, particularly in the light of the pressurised and politicised environment of the target group. In respect of the political parties, $71 \%$ of all UK constituencies are represented by Labour Party MEPs, $21 \%$ by Conservative Party members, and the remaining $8 \%$ shared between the Liberal Democrats, the Scottish National Party, and three Northern Ireland parties (the Democratic Unionist Party, the Ulster Unionist Party and the Social Democratic and Labour Party). The Labour/Conservative share was reflected in the survey response, with 63\% (19) from Labour MEPs and 23\% (6) from Conservative MEPs. The remaining returns were split equally between the Liberal Democrats and the SNP, 7\% (2) in each case. No responses were received from the parties in Northern Ireland

\section{Literature Review}

Very little literature exists on the subject of information retrieval amongst the Members of the European Parliament. Much of the European level literature concentrates on the documentation of the European Parliament and the policy of openness regarding public access to decisions and legislation, for example, via the European Documentation Centres, European Information Centres and Public Information Relay (see authors such as Thomson (1992a, 1992b and 1995), Hopkins (1986 and 1992) and Marcella et al (1997)).

The literature in the broad area of political information has tended to focus upon the role of the House of Commons Library and the development of new initiatives such as the POLIS (Parliamentary Online Information System) network. Menhennet has written extensively about the work of the House of Commons Library (see for example Menhennet (1982)). The POLIS system was described by Siswell (1986), Englefield (1982) and Menhennet and Wainwright (1982). Hancock-Beaulieu has 
investigated the use of online searching at the House of Commons. Tanfield (1993) discusses the challenges facing the House of Commons in seeking to support the differing information needs of members and the public. Martell (1994) describes the operation of the Parliamentary Labour Party Resource Centre which was established in 1991 to serve the information needs of Labour MPs, Peers and their staff, and to provide a current awareness service.

Kohl (1993) identifies four typical models of parliamentary library:

1. those serving only parliamentarians (such as the Congressional Research Service in the United States)

2. those for use by the entire political class, including trade unions, lobby groups, civil servants, citizens' action groups and the media (as in Germany)

3. those serving parliamentarians and the legal profession (as in Hungary)

4. those which combine the function of a parliamentary support service with the role of a national library deposit collection of materials

To these may be added:

- those which serve parliamentarians and the general public but specifically exclude certain groups such as the legal profession

This variety of provision has stemmed from the variant historical origins of parliamentary libraries, but it is particularly timely to review the advantages of the various models in the light of the establishment of the new Scottish Parliament and the Welsh Assembly.

Various articles describe the needs of parliamentarians in other countries, such as the paper by Freidin (1993), or the work of parliamentary libraries in other countries, see for example Freidin (1993) on Israeli parliamentarians' information needs and Liyawo (1986) on the Malazie parliamentary library. Ronai and Bryant (1992) argue that the Library of the Hungarian Parliament is an essential support service in the new freely elected national assembly, highlighting the significance of the provision of a non-partisan, accurate and timely information service in decision-making in legislative bodies. Zawislak (1992) also emphasises the importance of quality information in any decision-making process, in informing Polish citizens, external governments and businesses, and in creating an informed, knowledgeable population and healthy industry and economy. Online access to official information has been discussed in various national contexts by authors such as Sundholm (1997) and Mansfield (1997), while Lamont (1997) discusses the need for digital archiving of government information. 
Reid (1977) describes the European Parliament Research and Documentation Directorate General, identifying three problems with the service: the need to provide information and services in multiple languages; the problem of multiple site and remote access, with resources in Luxembourg, Brussels and Strasbourg and access required from the MEPs' home constituencies; and the ever growing range of subjects which require coverage. Baker and Rush's (1970) study of the information needs of the British MP, although dated, concludes that speed is the most significant aspect of information retrieval for MPs, and that less experienced MPs are more inclined to request additional information in the form of reports and policy analyses.

The results of a user survey of the House of Commons Library (Levin and Stonefield, 1995) indicated that the library was considered to be a crucial source of information in support of decision-making, by both MPs and their staff. While the library was used by most in combination with other government departments, lobbying bodies, unions, etc., the non-partisan aspect and speed of service of the library ensured that it was valued above most other sources. This assertion of the speed of response and accuracy as the most important aspects of information retrieval reflects the findings of earlier studies. Tomlinson (1996) describes the techniques he employs as an MEP to access European Parliament documentation, including electronic sources available, such as the multilingual OVIDE/EPISTEL service.

Through the Union's policy on openness, citizens are able to access a wealth of information on all aspects of European Union legislation, policy decisions and funding initiatives. However, there has been no recorded research into the methods employed by MEPs to access information essential to the decision-making process.

\section{The role of information as part of the decision making processes}

A decision-making process is a course of action or procedure which results in a formal judgement or choice being reached. For this to be possible, choices or options must be provided from which selection can be made. The ability to evaluate or choose from a range of options is underpinned by access to accurate, reliable and comprehensive information about the choices available. It is essential that decision makers have access to information that is free of bias and/or that reflects the full range of opinion existing. The transformation of information about these options into knowledge or 
intelligence is central to the effectiveness of the decision making process. Zawislak (1992) contends that the quality of the decision relies upon the quality of the information available. Robinson, Deputy Director of the Congressional Research Service, argues that 'a cornerstone of a strong democracy is an effective and independent legislature, and that an effective and independent legislature must first be an INFORMED legislature' (Ronai and Bryant, 1992, p. 143).

The disciplines of political science and policy analysis have developed a number of models to explain the process of decision-making more clearly, and the role of information within that process. Simon (1945) reduces the process to three stages:

- Intelligence

- Design

- Choice.

This is an overly simplified model of the use of information in decision-making, however it does highlight the importance of information. A more detailed examination of the process can be seen in Jenkins' seven stage model (1978):

- Initiation

- Information

- $\quad$ Consideration

- Decision

- Implementation

- Evaluation

- $\quad$ Termination.

In the initiation stage the problem is defined and the necessary steps for gathering relevant information and options are undertaken. Once this knowledge has been collated, it can be considered and a decision reached. The implementation of the policy decision is followed by an evaluation or assessment of the policy in action, from which changes can be made or the decision-making process completed. In the case of long term policies (such as funding for essential services), Jenkins argues that this process becomes cyclical - the decision made, assessed and continually adapted in order to respond to changing circumstances and events.

Bulmer's (1990) lineal model of decision-making, the engineering model of research, identifies five stages: 
(1) Definition of social problem;

(2) Identification of missing knowledge;

(3) Acquisition of social research data and relationships;

(4) Interpretation from problem solver;

(5) Policy change.

Bulmer contends that a problem exists due to a lack of information or understanding, which can be rectified by research. However, critics have argued that this conclusion does not recognise the fact that information is not a value-free commodity. A piece of knowledge, intelligence or advice will be affected by the source and the manner in which data supporting that knowledge, intelligence or advice was collated. Equally, preconceptions and ingrained beliefs amongst decision-makers will play a part in the choice between a number of options or the willingness to accept knowledge. High quality information and the availability of information reflecting the full range of opinion or belief are necessary underpinnings for decision making in order that bias of presentation and limited understanding may be combated.

The need for relevant, accurate and timely information to support decision-making has grown along with democratic governance and with the increasing complexity of government both nationally and supranationally. As more aspects of society become subject to legislation and forms of centralisation, the more knowledge MPs require to be able to take decisions in areas upon which they have little prior knowledge. This is a trend that continues with, for example, the need to understand the impact of technology upon contemporary society or the potential implications of genetic research.

With the increase in the range of subjects, issues, interests and disciplines of interest to parliamentarians, there has been a parallel increase in the quantity of information available, until we have today a general awareness of the concept of 'information overload'. This is a particularly testing problem for those in government: it is no longer possible for decision-makers to be expert in all areas, yet they must still make important decisions on complex issues. The need for a means of retrieving and selecting relevant and reliable information from this mass is of ever increasing importance. The problem is exacerbated by the increase of formats or media in which information may be accessed and by the increasing attractiveness of less traditional media, where quality of information may be more difficult to determine or where the quality apparatus has yet to develop fully. In order to measure the quality of information, two crucial elements must be examined, the validity of the information and the reliability of its source. 
Parsons (1995) categorises information available in government decision-making into four quadrants (see Figure 1).

\begin{tabular}{|l|l|}
\hline (1) Internal/Formal & (2) External/Formal \\
Departmental research/inquiry & Commissions \\
Internal think tank reports & Committees of inquiry \\
Reports from internal experts & $\begin{array}{l}\text { Judicial review } \\
\text { Reports from the legislature } \\
\text { Commissioned research } \\
\text { Formal consultation }\end{array}$ \\
\hline $\begin{array}{l}\text { (4) Internal/Informal } \\
\text { makermal discussions between decision- }\end{array}$ & $\begin{array}{l}\text { Discussions } \\
\text { Consultation }\end{array}$ \\
Gossip/Rumour & Reports \\
Informal use of advisers & Informal information/advice \\
& \\
\hline
\end{tabular}

Figure 1: Sources of Information in Government (Source: Parsons, 1995, p. 385)

Information within quadrant 1 may or may not be made public, but is essentially knowledge which is being generated within government; knowledge from quadrant 2 is generated wholly or in part outside the government machine; quadrant 3 encompasses information which may be obtained through informal discussions with experts or interest groups, such as professional organisations or trade unions, but will only be generated when commissioned by government; informal communications between government insiders is found in quadrant 4 .

Parsons argues that it is necessary to distinguish between knowledge generated or caused to come into existence by government, and knowledge existing independently. Information from within or 
associated with government may reflect internal policy or politically partisan ideals and beliefs. Outwith government, bodies such as the British Medical Association or the National Union of Farmers may produce information which reflects a professional perspective. Informational content will frequently show an element of bias. Tanfield (1993, p.27) similarly argues that one of the chief roles of the Library of the House of Commons is 'to offer Opposition spokesmen and backbenchers of all parties a source of information to balance as far as possible the information, advice and intellectual resources provided to Government Ministers by their civil servants'. It may be necessary for decision makers to assess all of the available sources to find the appropriate route to take: opposition parties may, however, rate the independent sources more highly than the government related ones, while the ruling political party may disregard external reports in favour of internally generated findings. Identification and understanding of the nature and source of information has a bearing on the determination of its quality; in the political arena the definition of quality may depend upon partisan considerations rather than being a pure and objective process.

In turn, it is necessary for the electorate itself to be informed of all decisions, policies and procedures of government to ensure against threats to the democratic process. In the case of the European Union, the policy of openness is achieved by the provision of information to all levels of society through the network of Commission Offices, Public Information Relays, European Documentation Centres and European Information Centres spread across the Member States. The need for transparency and openness in government within the European Union developed in the wake of the Maastricht Treaty. With the prospect of closer union and more decisions being made at a supranational level, it was felt that the European public would increasingly demand the right to question the aims and policies of the Union. The European Commission sought to develop an information policy that would be relevant, demand oriented and well co-ordinated in order to ensure coherence (European Commission, 1994). The Sutherland Report (1993) had highlighted the importance of targeting appropriate information efficiently so that it would reach its sectoral audience in a timely and easily understood manner. The concept of openness in the decision-making process was perceived to be mutually beneficial to the Union and to the electorate, the argument being that the more informed the citizens of Europe are of the procedures and decisions of government, the greater the democratic legitimacy of the European institutions. In turn, the confidence of the electorate in the administration depends on the public's knowledge and understanding of the Union and its aims and policies.

Democratic governance demands that the wishes of the electorate be represented at all levels, from 
local councillors managing specific regional concerns to MPs dealing in matters of national and international importance. The public is perceived as demanding an ever higher degree of accountability from its chosen representatives. To engender confidence among the electorate in the administration, the government at all levels must be prepared to provide explanations for and justifications of policy and decisions. Therefore, information is required on two main levels: information to aid the decision-makers in the formation of policy; and information to make the public aware of policy decisions, and to ensure that they fully understand those decisions.

\section{The MEP and the European Parliament}

There are many similarities between the role of Members of the European Parliament and those of the national parliaments as well as some major differences, and these can be highlighted by a brief comparison between members of the United Kingdom House of Commons and their European

colleagues. Both represent the interests of their constituents within the parliamentary process; in the case of the MEP the size and diverse nature of the constituency is greater than that of the MP. As in the House of Commons, MEPs sit in political, as opposed to national or regional, groupings transcending national borders. In both the UK and European parliaments MPs and MEPs split their time between that spent in parliament - in debate, plenary sessions and issue based or legislative committee work - and that spent in their constituencies. MEPs face comparatively greater problems in maintaining the confidence of their constituents due to their geographic remoteness from the constituencies they represent.

The problem of retrieving information available is compounded in Europe by the supranational diversity of publications, languages, cultures and national priorities across member states. Alongside the wealth of parliamentary documentation (in all 11 official languages), there are publications from the other European institutions, the various national parliaments of the member states, and numerous independent organisations and institutions. There are notorious difficulties in, for example, comparing statistics across member states because of the differences in composition of population, industry, social services and education. Finally, cultural and ideological differences across the member states are more pronounced than those within an individual nation-state, and may affect how issues are viewed. MEPs must guard against taking too parochial a view in decision making.

The role of the European Parliament within the Union is becoming increasingly significant. As the 
only institution formed through direct universal suffrage across the continent, the Parliament provides the Union with political legitimacy. The Parliament is charged with representing the interests of and guiding the European legislature to the benefit of all citizens of the European Union. The Parliament achieves this through: legislation; budgetary control; and supervision of the executive and administrative branches. The EP equally faces new challenges in accomplishing its vision of a broadening and deepening of union through enlargement and subsidiarity. The increased powers of parliament puts the onus on parliamentarians to take the lead in facing new challenges and opportunities. The individual members of the Parliament must assess present procedures and develop new ones to successfully fulfil their responsibilities to the citizens of Europe. The way in which the decision-making process is carried out is of paramount concern in the continually changing economic and political climate.

MEPs and their assistants draw upon the European Union's information services, in particular the European Parliament Library Service and the online and documentation services available through DGX of the European Commission.

\section{Information Requirements of United Kingdom Members of the European Parliament}

In order to understand the complexity of the problems involved in retrieving relevant information, it was felt to be important to first establish the range of subjects which are of interest to MEPs. There are four main levels at which information is required: constituency; party; European Parliament; and international.

At a constituency level, MEPs need to be able to respond to any questions their constituents may have on how the European Union affects them, their families and employment. Also MEPs have a responsibility to the local area as a whole, both economically and politically. Therefore, as well as being quite wide ranging, areas of interest at constituency level can be particular to the region (see Figure 2). Any information service catering to the needs of MEPs must, therefore, be prepared to respond to constituency level queries and not simply matters at a European level. The MEP will frequently see the constituency as first priority, in particular in terms of maintaining constituents' confidence and votes at future elections. 


\begin{tabular}{|l|l|}
\hline General - across European member states & Specific - regional interest \\
\hline European Union Funding & Fishing \\
European Union Legislation & Agriculture \\
Regional Policy & Brewing \\
Economy & Ceramics \\
Employment & Local Transport, etc. \\
Education & \\
Environment, etc. & \\
\hline
\end{tabular}

Figure 2: Areas of interest at constituency level

At a party level, MEPs' interests cover all active policy areas. As their parties' representatives in Europe, MEPs often act as party spokesperson on European Affairs in general, in addition to those areas of European policy which concern the UK directly, such as fishing and agriculture, health, welfare and employment legislation, and constitutional affairs.

Within the European Parliament, MEPs' areas of interest reflect their constituency and party concerns. The major areas identified by the questionnaire were economic and monetary union, fishing and agriculture, health and social affairs, transport and tourism, and regional policy. Also considered to be of great importance were the more topical issues of BSE and EU enlargement.

At an international level, the areas of interest match the European Parliament's many subcommittees and groupings. Respondents expressed information requirements in the areas of EU enlargement, Security and Disarmament, Human Rights, and International Economics, in addition to needs relating to specific geographic regions (see Figure 3). 


\begin{tabular}{|l|l|}
\hline Geographical Areas & Supranational issues \\
\hline Eastern Europe & European Union enlargement \\
Former Soviet Union & Security and Disarmament \\
Mediterranean & Human Rights \\
Middle East & International Economics \\
South East Asia & \\
Africa & \\
North America & \\
The developing world & \\
\hline
\end{tabular}

Figure 3: Areas of interest at international level

At all four levels, information is gathered from a variety of sources and in varying formats (see Figure 4). At a constituency level, information from the local community and media is as important as that from formal sources such as European Union publications, party documents, etc. Within the party, informal contacts and policy decisions and briefings from Westminster colleagues give additional information which may not be available through the more general sources. At the European Parliament level, internal publications, reports, meetings and briefings were all held to contain important information which could be crucial in supporting decision making. Finally, at an international level, foreign and specialist media and informal contacts provide alternative views and information to those of internal European agencies. 


\begin{tabular}{|l|l|}
\hline General responses - sources employed & At specific levels - sources employed \\
\hline Media - international and specialist & Constituency: \\
Pressure Groups & Local media \\
Professional Organisations & Councils/local authorities \\
Trade Unions & Party: \\
National Government & Informal Contacts \\
Internet & UK MPs \\
European Regulations & UK policy decision/briefings \\
EP Proposals & European Parliament: \\
Official European reports and documentation & Official European Publications \\
Informal contacts & Reports/briefings \\
& Meetings \\
& International: \\
& Foreign/Specialist Media \\
& Informal Contacts \\
\hline
\end{tabular}

Figure 4: Sources of information used by respondents

All MEPs have research assistants to help them with their duties. The majority of respondents, $87 \%$ (26 respondents), have three or more research assistants, while 10\% (three respondents) have two research assistants. Only one respondent had just one research assistant (see Figure 5).

\begin{tabular}{|c|c|c|}
\hline Number of Assistants & Number of Respondents & $\%$ \\
\hline 1 & 1 & $3 \%$ \\
\hline 2 & 3 & $10 \%$ \\
\hline $3+$ & 26 & $87 \%$ \\
\hline
\end{tabular}

Figure 5: Number of research assistants 
In total the 30 respondents have 104 research assistants, giving an average of 3.5 research assistants per MEP. Of these 104 research assistants, the majority are based in the UK constituencies, 63\% (66 researchers), while 32\% (33 researchers) are based in Brussels and 5\% (5 researchers) in Strasbourg (see Figure 6). While most MEPs appear to have research assistants based in more than one location, one respondent has a sole research assistant based in the UK. A high number of these research assistants are full-time, 69\% (72 of 104), with only 31\% (32 of 104) employed on a part-time basis.

In relation to their location, most research assistants based in the UK constituencies and Brussels are employed full-time, 62\% (41 of 66) and 88\% (29 out of 33) respectively. In contrast those working in Strasbourg are more likely (60\%) to be part-time (see Figure 6).

Figure 6: Mode of employment and location of researchers

\begin{tabular}{|l|l|c|c|}
\hline Location & Status & Number of Assistants & $\%$ \\
\hline United Kingdom & Full-time & 41 & $62 \%$ \\
& Part-time & 25 & $38 \%$ \\
\hline Brussels & Full-time & 29 & $88 \%$ \\
& Part-time & 4 & $12 \%$ \\
\hline Strasbourg & Full-time & 2 & $40 \%$ \\
& Part-time & 3 & $60 \%$ \\
\hline
\end{tabular}

(Brussels Full-time includes three who also cover Strasbourg).

The majority of MEPs $(25,83 \%)$ conduct some of their own research while also calling upon their researchers for assistance. Only 17\% (i.e. five) of the MEPs delegated all their research queries to their assistants. Unsurprisingly no respondents undertook all their own research.

In order to establish which sources of information were most used and how useful these sources were considered to be, each MEP was given a list of nine sources and asked to rate them in order of preference. However, this question was misinterpreted by some respondents, who only marked those sources they actually used. Therefore two sets of results were recorded for this question. Results were first calculated in terms of the number of respondents using each source. (See Figure 7) 
Figure 7: Sources of information

\begin{tabular}{|l|c|c|}
\hline Source & Number of Respondents & $\%$ \\
\hline Informal contacts & 30 & $100 \%$ \\
\hline MEPs' own files & 28 & $93 \%$ \\
\hline European Parliament Library Service & 25 & $83 \%$ \\
\hline Political party offices & 25 & $83 \%$ \\
\hline Internet & 22 & $73 \%$ \\
\hline UK House of Commons Library Service & 19 & $63 \%$ \\
\hline EUR-OP & 17 & $60 \%$ \\
\hline EPOQUE & 17 & $57 \%$ \\
\hline OVIDE/EPISTEL & & $57 \%$ \\
\hline
\end{tabular}

The most frequently used sources were found to be unofficial, informal contacts (100\%) and MEPs' own files (93\%), followed by the European Parliament Library Service and political party offices (both 83\%). The Internet received a high number of responses (73\%): however one respondent stated that they did not yet have access to the World Wide Web. The UK House of Commons Library Service also has a role in providing information to MEPs: $63 \%$ of respondents used this source. The least popular sources were all official European sources: EUROPA, the European Commission's web site (60\%); EPOQUE, an online database providing access to parliamentary documents, debates, decisions, replies, articles and factsheets (57\%); and OVIDE/EPISTEL, a service designed for Members, officials and agents of the European Parliament, which allows electronic access to official documentation, calendar information, agendas, directories, emails and electronic forms (57\%) (See Figure 7). Respondents demonstrate a heavy reliance upon informal sources and contacts, while showing much less enthusiasm for official sources, particularly when these are held in electronic form.

For respondents who expressed a rate of preference for the above sources, a ranking scheme was developed with 9 points for the most useful and preferred source through to 1 for the least useful and 
preferred (see Figure 8). The most valued sources matched those most frequently used by MEPs and their research assistants.

\begin{tabular}{|c|c|c|c|c|c|c|c|c|c|c|c|c|}
\hline \multicolumn{10}{|c|}{ Figure 8: Levels of satisfaction with information sources } & & & \\
\hline \multirow[t]{2}{*}{ Information Source } & \multirow{2}{*}{$\begin{array}{l}\text { Total no of } \\
\text { respondents } \\
\text { citing }\end{array}$} & \multicolumn{11}{|c|}{$\begin{array}{l}\text { Level of satisfaction: (9 most - } 1 \text { least) } \\
\text { Number of Respondents citing and score }\end{array}$} \\
\hline & & 9 & 8 & 7 & 6 & 5 & 4 & 3 & 2 & 1 & Total & Rank \\
\hline MEPs' own files & 21 & $\begin{array}{l}12 \\
108\end{array}$ & $\begin{array}{l}2 \\
16\end{array}$ & $\begin{array}{l}5 \\
35\end{array}$ & $\begin{array}{l}- \\
0\end{array}$ & $\begin{array}{l}- \\
0\end{array}$ & - & 0 & $\begin{array}{l}2 \\
4\end{array}$ & $\begin{array}{l}- \\
0\end{array}$ & 163 & $1 \mathrm{st}$ \\
\hline $\begin{array}{l}\text { European Parliament } \\
\text { Library Service }\end{array}$ & 20 & 6 & $\begin{array}{l}2 \\
16\end{array}$ & $\begin{array}{l}6 \\
43\end{array}$ & $\begin{array}{l}3 \\
18\end{array}$ & 2 & $\begin{array}{l}1 \\
4\end{array}$ & 0 & $\begin{array}{l}- \\
0\end{array}$ & - & 145 & 2nd \\
\hline Informal contacts & 21 & $\begin{array}{l}4 \\
36\end{array}$ & $\begin{array}{l}8 \\
64\end{array}$ & $\begin{array}{l}2 \\
14\end{array}$ & $\begin{array}{l}2 \\
12\end{array}$ & 2 & $\begin{array}{l}1 \\
4\end{array}$ & 3 & $\begin{array}{l}- \\
0\end{array}$ & $\begin{array}{l}1 \\
1\end{array}$ & 144 & $3 \mathrm{rd}$ \\
\hline Political party offices & 19 & $\begin{array}{l}1 \\
9\end{array}$ & $\begin{array}{l}1 \\
8\end{array}$ & $\begin{array}{l}5 \\
35\end{array}$ & $\begin{array}{l}2 \\
12\end{array}$ & $\begin{array}{l}3 \\
15\end{array}$ & 4 & 3 & $\begin{array}{l}- \\
0\end{array}$ & $\begin{array}{l}2 \\
2\end{array}$ & 100 & 4 th \\
\hline Internet & 17 & $\begin{array}{l}1 \\
9\end{array}$ & $\begin{array}{l}3 \\
24\end{array}$ & $\begin{array}{l}- \\
0\end{array}$ & $\begin{array}{l}6 \\
36\end{array}$ & 2 & $\begin{array}{l}2 \\
8\end{array}$ & 1 & $\begin{array}{l}1 \\
2\end{array}$ & $\begin{array}{l}1 \\
1\end{array}$ & 93 & 5 th \\
\hline OVIDE/EPISTEL & 15 & $\begin{array}{l}- \\
0\end{array}$ & $\begin{array}{l}3 \\
24\end{array}$ & $\begin{array}{l}2 \\
14\end{array}$ & $\begin{array}{l}2 \\
12\end{array}$ & $\begin{array}{l}- \\
0\end{array}$ & $\begin{array}{l}1 \\
4\end{array}$ & 1 & $\begin{array}{l}- \\
0\end{array}$ & $\begin{array}{l}2 \\
2\end{array}$ & 71 & 6 th \\
\hline EPOQUE & 15 & $\begin{array}{l}- \\
0\end{array}$ & $\begin{array}{l}2 \\
16\end{array}$ & $\begin{array}{l}2 \\
14\end{array}$ & $\begin{array}{l}- \\
0\end{array}$ & $\begin{array}{l}5 \\
25\end{array}$ & $\begin{array}{l}1 \\
4\end{array}$ & 3 & $\begin{array}{l}2 \\
4\end{array}$ & $\begin{array}{l}2 \\
2\end{array}$ & 68 & 7 th \\
\hline $\begin{array}{l}\text { UK House of Commons } \\
\text { Library Service }\end{array}$ & 12 & $\begin{array}{l}2 \\
18\end{array}$ & $\begin{array}{l}- \\
0\end{array}$ & $\begin{array}{l}1 \\
7\end{array}$ & $\begin{array}{l}1 \\
6\end{array}$ & $\begin{array}{l}1 \\
5\end{array}$ & $\begin{array}{l}1 \\
4\end{array}$ & 6 & $\begin{array}{l}4 \\
8\end{array}$ & $\begin{array}{l}3 \\
3\end{array}$ & 57 & 8 th \\
\hline EUROPA & 12 & $\begin{array}{l}- \\
0\end{array}$ & $\begin{array}{l}3 \\
24\end{array}$ & $\begin{array}{l}1 \\
7\end{array}$ & $\begin{array}{l}- \\
0\end{array}$ & - & $\begin{array}{l}2 \\
8\end{array}$ & 2 & $\begin{array}{l}3 \\
6\end{array}$ & $\begin{array}{l}4 \\
4\end{array}$ & 55 & 9th \\
\hline
\end{tabular}

Using this ranking system the European Parliament Library Service emerges as a valued resource for respondents, but it remains flanked by informal contacts and MEPs internal files. Despite its recency in comparison to the other electronic sources, the Internet as a broad resource is merited more highly 
than the other databases. A significant number of respondents cited a low level of satisfaction with electronic databases and the House of Commons Library Service.

Only a minority of respondents (nine, 30\%) felt that they had encountered problems retrieving information in the past, while $15(50 \%)$ had experienced no difficulties and six (20\%) did not respond. Respondents who had encountered problems were asked to provide examples. The majority expressed frustration at the amount of information available from a myriad of sources: in comments such as, 'you need to spend 6 months finding out what is available from where, before you can even look for the information you want!'

MEPs and research assistants found that they had to rely on experience to answer enquiries and identify what was relevant from the wealth of information available in forms such as pamphlets, books, official documentation, articles and guides. Much information is sent to them by a variety of groups and organisations: this is often unsolicited material which must be weighed, evaluated and digested by the MEP, but is often more simply added uncritically to files. More specifically, attempting to find more obscure details about the new democracies of Eastern Europe and on individual specialised subjects such as energy and research had caused difficulties for respondents in the past.

Complaints about the electronic services used were many and varied. The expense of accessing the EU databases was highlighted, as was the poor quality of search engines on these databases and on European websites: EUROPA, for example, was described as 'not working well and not very user friendly'. Other technical problems were mentioned such as computer breakdown and the slow response rate of the European Parliament document delivery service. Respondents had also encountered problems in making contact with and obtaining information from individual organisations and institutions as a result of inaccurate or out of date directory information.

\section{Conclusions}

From the variety of interest and information need demonstrated by respondents it is clear that those involved in decision-making in the European Parliament face challenges in ensuring access to the full range of information available on a topic. From relatively small and localised enquiries, such as the effect of EU legislation on the manufacture of a particular product in one constituency, to Europe 
wide concerns, such as the annual budget, MEPs must be able to make considered decisions. The enlargement of the Union will exacerbate the situation, as will the increased profile of the Union in international affairs.

Major problems arise for MEPs in relation to: the variety of subject upon which they might be called to take decisions; their frequent lack of prior knowledge; the unpredictability of need; the crisis driven pattern of demand; the need to access information speedily and in a reactive manner; the multi-site nature of European parliamentary activity; the need to develop multi-national understanding and perspective; the growth in the amount of information, official and non-official; and the existence of new forms of access to information that were felt by respondents to be insufficiently user friendly.

Knowledge of sources available, the relevance of their content, and an ability to access them efficiently and cost-effectively are necessary in those executing information searches. It is worth noting that searches may be carried out by Research Assistants or by MEPs directly. It is unlikely that a majority of MEPs and their researchers have even rudimentary information skills training. The main problem perceived by respondents in relation to existing information retrieval techniques was the sheer volume of information available, and the seemingly impossible task of identifying the most relevant information and determining the quality of information from variable sources. However, only $30 \%$ admitted to having problems in retrieving information. Clearly the majority were not conscious of problems or deficiencies: this does not mean that these do not exist.

The most used sources were informal contacts and MEPs' own files - both unofficial sources. The European Parliament Library Service and political party offices were also popular and valued resources: however the official European Union electronic information services, EUROPA, EPOQUE and OVIDE/EPISTEL, were least used and valued. Access problems, including expense of connection, were highlighted by respondents as reasons for dissatisfaction. While content was appropriate, these services were not felt to be user friendly. There was a low level of satisfaction with the Internet as an information source despite comparatively high levels of use.

Informal contacts were considered to be the most important and reliable source of information for all MEPs. This result replicates Parsons' Internal/Informal and External/Informal categorisation of sources and includes contacts with various groups, organisations and individuals, both associated with and independent of the European Parliament and respective national parliaments. Constituents, 
interest groups, professional bodies, trade unions, and business organisations all provide information of varying quality on issues which concern them. At present there seems to be no accepted mechanisms amongst MEPs to determine the quality of this non-official information. In order for the public to have confidence in the decision-makers, they must also have confidence in the information on which their decisions are based. As Tanfield argues:

'We believe that well-informed members of the legislature are vital to a democracy and that if the Library's [of the House of Commons] information and research service fails to meet members' needs the many organisations outside Parliament who have particular points of view to impart will seek to fill the vacuum.' (Tanfield, 1993, p.30)

Means of evaluating this heavily relied upon 'informal' information (as well as that obtained from conventional sources) must be developed, possibly through some form of review process at European or subject level similar to the development of Clinical Trial Reviews in the health care sector. Research into the role of information in the decision-making process within the health care sector has been extensive and a number of initiatives put into operation to improve procedures and ensure the quality of the decisions being made. However in the field of political decision-making there has been a significant lack of research into the role of information. Only when the effectiveness of present procedures and the quality of information, upon which processes are based, have been measured, can improvements in services and sources be achieved. A better understanding of the present information needs and information seeking patterns of decision makers and their researchers, perhaps based upon Eager and Oppenheim's (1996) observational method, is fundamental to the achievement of this objective. 


\section{References}

Andersen, S.S. and Eliassen, K. (1993) . Making policy in Europe. London: Sage.

Archer, C. (1994) . Organising Europe. London: Edward Arnold.

Baker, A. and Rush, M. (1970) . The Member of Parliament and his Information. London: George Allen \& Unwin.

Bulmer, M. (1990) . Successful applications of sociology. In Bryant, C.G.A. and Becker, H.A. (Eds.) What has sociology achieved? London: MacMillan.

Cochrane Collaboration. (1997). The Cochrane Collaboration, Available online at: URL: http://hiru.mcmaster.ca/cochrane/overview.htm Accessed March 1998.

Department of Health. (1989) . Working for patients. London: HMSO.

Eager, C. and Oppenheim, C. (1996). An observational method for undertaking user needs studies. Journal of Librarianship and Information Science, 28(1), pp. 15 - 23.

Englefield, D. (1982) . How the Parliamentary Online System at Westminster was designed. Inspel, 16 (3), pp $154-165$.

EUROPA. (1997) . What is the European Union? Available online at URL: http://europa.eu.int/ Accessed March 1998.

European Commission. (1994) . Information, Communication, Openness. Brussels: European Commission. [ISEC/B25/94]

Freidin, H. (1993) . The information requirements of Israeli Parliamentarians (Knesset Members); findings of a survey. Information and Librarianship, 20 (1), pp 11 - 14.

Hancock-Beaulieu, M. (1990) . Online searching at the House of Commons. Library and Information Research News, 13 (49), pp 6 - 7.

Hopkins, M. (1992) . The supply and demand for EC business information in the United Kingdom. Aslib Proceedings, 44(5), pp. 207 - 211.

Hopkins, M. and Bingham, G. (1986) . The business use of European Communities information in the United Kingdom. London: British Library.

Jenkins, W.I. (1978) . Policy analysis: a political and organisational perspective. London: Martin Robertson.

Kohl, E. (1993) . Whom should the parliamentary library serve? In IFLA Council and Conference: proceedings of the 59th Council and Conference, Barcelona, Spain, 22-28th August, 1993. IFLA. Booklet 1, Division of Research Libraries, pp. 22-23.

Lamont, M. (1997) . Here today, gone tomorrow? Preserving electronic government information for the future. In IFLA General Conference: proceedings of the 63rd IFLA Conference, Copenhagen, 31st August 5th September, 1997. IFLA. Booklet 5, Division of Collections and Services, pp. 12 - 14.

Levin, J. and Stonefield, E, (1995) . House of Commons Library User Survey: Report on Research amongst Members and Staff. London: Levin Associates.

Liyawo, B.B. (1986) . The role of the Malazie Parliament Library to members of parliament, administrative staff and outside users. MALA Bulletin, 4 (2), pp. 17 - 21. 
Mansfield, J.W, (1997) . Wings across America: the U.S. Postal Service delivers electronic government information. In IFLA General Conference: proceedings of the 63rd IFLA Conference, Copenhagen, 31st August - 5th September, 1997. IFLA. Booklet 5, Division of Collections and Services, pp. 5 - 11.

Marcella, R., Baxter, G., and Parker, S. (1997) . The provision of European Union information by public libraries in the IK: results of a British Library Research and Innovation Centre funded research project. Library Management, 18 (1), pp. 7 - 41.

Martell, V. (1994) . Providing an information service to MPs: the Labour Party Resource Centre at the House of Commons. Assignation, 11 (2), pp. 30 - 33. [Whole issue devoted to political information].

Menhennet, D. and Wainwright, J. (1982). POLIS in parliament: computer-based information retrieval in the House of Commons Library. Journal of Documentation, 38 (2), pp 72 - 93.

Menhennet, D. (1982) . The House of Commons Library at Westminster. Journal of Librarianship, 14 (2), pp $79-92$.

NHS Centre For Reviews \& Dissemination (1996) . Undertaking systematic reviews of research on effectiveness: CRD guidelines for those carrying out or commissioning reviews. York: NHS CRD.

Nugent, N. (1994) . The government and politics of the European Union. London: Macmillan.

Parsons, W. (1995) . Public policy: an introduction to the theory and practice of policy analysis. Aldershot: Edward Elgar.

Reid, A.S. (1977) . Information for the Member of Parliament, The Information Scientist, 11(3), pp. 43 - 51.

Ronai, I. and Bryant, M.N. (1992) . The role of Hungary's Parliamentary Library in fostering democratic decision making. Libri, 42 (2), 1992, pp 136 - 143.

SHPIC. (1997). Scottish Health Purchasing Information Centre. Aberdeen: SHPIC.

Simon, H.A. (1945) . Administrative behaviour. New York: Free Press.

Siswell, A. (1986) . POLIS: the Parliamentary Online Information System. Law Librarian, 17 (1), pp. 23 - 26.

Sundholm, E. (1997) . The ODIN: the central web server for official documentation and information from Norway. In IFLA General Conference: proceedings of the 63rd IFLA Conference, Copenhagen, 31st August - 5th September, 1997. IFLA. Booklet 2, Division of Special Libraries, pp. 34 - 36.

Sutherland, P. (1992) . The internal market after 1992: meeting the challenge: report to the EU Commission by the High Level Group on the Internal Market. Luxembourg, OOPEC.

Tanfield, J. (1993) . Services for Members: services for the public - the dual mandate of the Library Department of the House of Commons. In IFLA Council and Conference: proceedings of the 59th Council and Conference, Barcelona, Spain, 22-28th August, 1993. IFLA. Booklet 1, Division of Research Libraries, pp. 27 - 30.

Thomson, I. (1992a) . European Documentation Centres: their role in EC information provision with particular reference to the UK. Government Publications Review, 17(2), 1990, pp 107-119.

Thomson, I. (1992b) . European Community information providers in the UK: the role of European Documentation Centres. Refer, 8 (1), p. 9.

Thomson, I. (1995) . Challenges facing European Documentation Centres. European Access, 6, pp. 16 - 19.

Tomlinson, J. (1996) . Accessing European Parliament Documentation. Available online at:URL: 
http://www.poptel.org.uk/john.tomlinson/epdoc.html Accessed March 1998.

Urwin, D. (1991) . The Community of Europe: A history of European integration since 1945. London: Longman.

Zawislak, A. (1992). The role of information in Poland's industrial reforms. Aslib Proceedings, 44 (1), pp. 21 -22 . 